Фармацевтичний менеджмент, маркетинг та логістика

Pharmaceutical management, marketing and logistics

Рекомендована д. фрармац. наук, профр. Т. Г. Калинюком

УДК 615.15:371.71]:616.995.42-084

DOI 10.11603/2312-0967.2018.2.9123

\title{
ОСОБЛИВОСТІ РОЗУМІННЯ СТУДЕНТАМИ-ПРОВІЗОРАМИ ПРОБЛЕМИ ЗАПОБІГАННЯ КЛІЩОВИМ ТРАНСМІСИВНИМ ПРИРОДНО-ОСЕРЕДКОВИМ ІНФЕКЦІЯМ
}

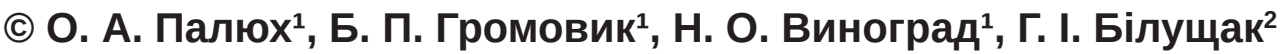 \\ Львівський національний медичний університет імені Данила Галицького ${ }^{1}$ \\ Національний університет «Львівська політехніка»² \\ oksana.paliuh@gmail.com,hromovyk@gmail.com, \\ vynogradno@ukr.net,gbilushak@gmail.com
}

\begin{abstract}
Мета роботи. Дослідження рівня знань студентів-провізорів денної форми навчання щодо можливості надання фрармацевтичної допомоги з питань запобігання зараженню збудниками небезпечних трансмісивних інфеекційних захворювань, переносниками яких є іксодові кліщі (IK).

Матеріали і методи. Для збору первинних даних використовували очно-заочне опитування з використанням анкет відкритого типу. Отримано 443 анкети, з яких відібрано та опрацьовано 429 якісно заповнених анкет. Статистичний аналіз граничної похибки частки проводився з використанням табличного процесора Microsoft Office.

Результати й обговорення. Встановлено, що, на думку більш як трьох четвертих студентів, ІІ є, насамперед, переносниками збудників кліщового вірусного енцесраліту. Проте дещо менше однієї третьої опитаних зазначили у відповідях, що ІК є збудниками корости, хоча це захворювання спричиняє кліщ Sarcoptes scabiei. Близько трьох четвертих студентів вважали, що для запобігання укусам ІК доцільно одягатися у світлий однотонний з довгими рукавами щільно прилеглий до тіла одяг. Більшість анкетованих зазначила доречність проведення регулярних само- і взаємооглядів, а більш як одна п'ята - використання репелентів як хімічних засобів захисту. Проте застосування комплексних заходів захисту характерне лише для понад п'ятої частини опитаних. Дві п'яті студентів правильно вказали на доречність застосування вакцини проти кліщового вірусного енцесраліту Проте опитані усіх курсів неправильно обрали інші хвороби щодо вакцинації. Усі, без винятку, студенти не ознайомленні 3 можливими місцями локалізації ІК. Понад двадцятої частини студентів, які стикалися з укусами ІК, видаляла їх просто пальцями рук, що категорично заборонено. Менш як дві третини студентів використовували комбінований спосіб видалення ІК. Результати вивчення навчального плану показали, що студенти-провізори упродовж всього освітнього процесу не вивчають питання запобігання зараженню збудниками небезпечних трансмісивних інфекційних захворювань, переносниками яких $€ \mathrm{IK}$.

Висновки. Шляхом анкетного опитування 429 студентів-провізорів першого-п'ятого курсів денної фрорми навчання встановлений недостатній рівень їх знань щодо надання фрармацевтичної допомоги з питань запобігання зараженню небезпечними трансмісивними інфекційними захворюваннями, переносниками яких є ІК. Зважаючи на автономність закладів вищої освіти та відсутність курсу епідеміології при підготовці магістрів фрармації, актуально внести зміни в навчальні плани університетів фрармацевтичного спрямування, зосередивши увагу на захворюваннях, збудниками яких $€ \mathrm{IK}$, а також на засобах індивідуальної неспецифрічної профрілактики цих інсрекцій, зокрема аптечного асортименту.
\end{abstract}

Ключові слова: іксодові кліщі; природно-осередкові інфекції; студенти-провізори; рівень знань.

Вступ. Іксодові кліщі відомі як переносники збудників багатьох природно-осередкових інфекційних хвороб, серед них: кліщовий вірусний енцесраліт, Лайм-бореліоз, Кримсько-Конго геморагічна гарячка, анаплазмоз, ерліхіоз, туляремія, кліщові рикетсіози тощо [1]. Передача цих збудників людині відбувається найчастіше трансмісивним шляхом у весняноосінній сезон на будь-якій зарослій щільною рослинністю або травою місцевості - за місцем проживання, на присадибних ділянках і територіях відпочинку, на незатоплюваних заплавах річок і берегах озер, в лі- сопарках та листяних лісах. Знання заходів запобігання зараженню збудниками трансмісивних природно-осередкових інфекцій дозволяє значно знизити шкоду життю людей, що й визначило спрямування цієї роботи.

Аналіз нормативних документів показав, що у методичних рекомендаціях [1] докладно розглядаються питання, які стосуються специфічної та неспецифічної профрілактики нападу ІК. Накази МОЗ України [2, 3] регламентують заходи для діагностики та методи специфічної профрілактики щодо зараження збудни-

ISSN 2312-0967. Фармацевтичний часопис. 2018. № 2 
Фармацевтичний менеджмент, маркетинг та логістика Pharmaceutical management, marketing and logistics

ками небезпечних захворювань. В інфрормаційному листі [4] викладені питання щодо неспецифрічної профрілактики кліщового вірусного енцефаліту, іксодових кліщових бореліозів та інших інорекцій, збудники яких передаються IК. Утім зростання захворюваності населення на інфекції, які передаються ІК, свідчить про недостатню поіноормованість людей з приводу цих захворювань. Тому спрямуванням нашої роботи було визначення рівня знань студентів щодо ІК як векторів збудників природно-осередкових інфекцій.

Мета роботи дослідження рівня знань студентівпровізорів денної форми навчання щодо можливості надання фрармацевтичної допомоги з питань запобігання зараженню збудниками небезпечних трансмісивних інфекційних захворювань, переносниками яких $€ \mathrm{IK}$.

Матеріали і методи. Для збору первинних даних використовували очно-заочне опитування. Дизайн дослідження характеризувався такими параметрами: інструмент збору даних - анкета, соціальна група опитаних - студенти-провізори першого-п'ятого курсу очної форми навчання, період збору даних - жовтень-грудень 2017 р. Конфрлікт інтересів відсутній. Отримано 443 анкети, з яких відібрано та опрацьовано 429 якісно заповнених анкет. Серед опитаних було 74,3 \% осіб жіночої статі. їх вік коливався в межах від 17 років до 22 років при середньому значенні 19 років. Варто зазначити, що на деякі питання анкети респонденти мали можливість давати декілька відповідей.

Статистичний аналіз проводили 3 використанням табличного процесора Microsoft Office. Для оцінювання результатів опитування використовували величину частки респондентів від опитаних, які вибрали відповідний варіант відповіді із запропонованих. Для оцінювання похибок частки використовували граничні похибки частки:

$$
\Delta=t \sqrt{\frac{m(1-m)}{n}\left(1-\frac{n}{N}\right)},
$$

де $m$ - частка, $n$ - кількість опитаних, що, $N$ - загальна кількість опитаних $t$ - параметр, що відповідає рівню надійності. Всі результати статистичного аналізу отримано з рівнем надійності (довіри) $95 \%$.

Результати й обговорення. За результатами проведеного дослідження встановлено (табл. 1), що, на думку більш як трьох четвертих студентів, IK $€$, насамперед, переносниками збудників кліщового вірусного енцефаліту. Окрім цього, понад половини опитаних зазначили кліщовий висипний тиср, більш ніж однієї третьої - Лайм-бореліоз. Менше однієї п'ятої респондентів вказали на гранулоцитарний анаплазмоз і моноцитарний ерліхоз людини. Десята частина зазначили марсельську гарячку і Ку-гарячку.

Проте дещо менше третини опитаних вказала у своїх відповідях, що ІК переносять збудників корости, хоча це захворювання спричиняє кліщ Sarcoptes scabiei. При цьому цю хворобу зауважили понад дві п'яті третьокурсників, менше третини четвертокурсників та більш як третина першокурсників, менше однієї п'ятої - студенти другого й п'ятого курсів. Аналізуючи дані статистичної обробки, варто зазначити, що у п'ятикурсників узгодженість думок спостерігалася у відповідях на запитання щодо кліщового вірусного енцесраліту, Лайм-бореліозу, моноцитарного ерліхозу людини та Ку-гарячки. Що стосується таких захворювань, як Кримсько-Конго геморагічна гарячка, марсельська гарячка, гранулоцитарний анаплазмоз людини та кліщовий висипний тиф, то тут ми спостерігали відсутність узгодженості думок, що свідчить про недостатню поінформованість студентів п'ятого курсу з приводу даних захворювань.

Важливе значення для захисту від ІК у частині неспецифічної профрілактики має вибір верхнього одягу

Таблиця 1. Результати опитування щодо кліщових трансмісивних захворювань

\begin{tabular}{|c|c|c|c|c|c|c|}
\hline \multirow{3}{*}{ Захворювання } & \multicolumn{5}{|c|}{$\begin{array}{c}\text { Позитивні відповіді студентів } \\
\text { з урахуванням курсу навчання (у \%) }\end{array}$} & \multirow{3}{*}{$\begin{array}{c}\text { Разом } \\
(\text { у \%) } \\
N=429\end{array}$} \\
\hline & 1 & II & III & IV & $\mathrm{V}$ & \\
\hline & $\mathrm{n}_{1}=70$ & $\mathrm{n}_{2}=81$ & $\mathrm{n}_{3}=113$ & $\mathrm{n}_{4}=96$ & $\mathrm{n}_{5}=69$ & \\
\hline Кліщовий вірусний енцефаліт & $92,9 \pm 3,0$ & $72,8 \pm 2,0$ & $77,8 \pm 2,6$ & $69,7 \pm 0,9$ & $81,6 \pm 8,3$ & $78,4 \pm 4,2$ \\
\hline Кліщовий висипний тифр & $65,7 \pm 5,6$ & $48,1 \pm 1,6$ & $62,8 \pm 2,3$ & $61,4 \pm 0,9$ & $51,8 \pm 11,1$ & $58,5 \pm 5,13$ \\
\hline Лайм-бореліоз & $58,6 \pm 5,9$ & $14,8 \pm 0,9$ & $27,4 \pm 1,5$ & $38,5 \pm 1,0$ & $58,3 \pm 9,6$ & $38,1 \pm 5,1$ \\
\hline $\begin{array}{l}\text { Гранулоцитарний анаплазмоз } \\
\text { людини }\end{array}$ & $24,3 \pm 5,1$ & $1,2 \pm 0,3$ & $7,9 \pm 0,8$ & $13,5 \pm 0,7$ & $36,2 \pm 10,8$ & $15,6 \pm 3,8$ \\
\hline Моноцитарний ерліхоз людини & $20,0 \pm 4,8$ & $4,9 \pm 0,5$ & $11,5 \pm 1,0$ & $10,4 \pm 0,6$ & $27,2 \pm 10,0$ & $14,2 \pm 3,6$ \\
\hline $\begin{array}{ll}\text { Кримсько-Конго геморагічна } \\
\text { гарячка }\end{array}$ & $20,0 \pm 4,8$ & $1,2 \pm 0,3$ & $2,6 \pm 0,5$ & $7,2 \pm 0,5$ & $32,4 \pm 10,5$ & $11,5 \pm 3,3$ \\
\hline Марсельська гарячка & $21,4 \pm 4,9$ & - & $3,5 \pm 0,5$ & $5,2 \pm 0,5$ & $25,9 \pm 10,1$ & $10,6 \pm 3,2$ \\
\hline Ку-гарячка & $15,7 \pm 4,4$ & - & $2,6 \pm 0,5$ & $10,4 \pm 0,6$ & $27,1 \pm 9,9$ & $10,0 \pm 3,1$ \\
\hline Короста & $37,1 \pm 5,8$ & $14,0 \pm 1,0$ & $43,3 \pm 1,9$ & $32,2 \pm 1,0$ & $19,4 \pm 8,5$ & $31,0 \pm 4,8$ \\
\hline
\end{tabular}

ISSN 2312-0967. Pharmaceutical review. 2018. № 2 
Фармацевтичний менеджмент, маркетинг та логістика Pharmaceutical management, marketing and logistics

для прогулянки в парк чи ліс, дотримання правил поведінки на небезпечній щодо ІК території та застосування спеціальних хімічних засобів від нападу IK $[1,2]$.

Як видно з даних таблиці 2, близько трьох четвертих студентів вважали, що для запобігання укусам IK доцільно одягатися в світлий однотонний з довгими рукавами щільно прилеглий до тіла одяг. При цьому найвище значення цьому надавали студенти першого курсу (більш як чотири п'ятих) і найменше (майже дві треті) - студенти третього і четвертого курсів.

Більшість анкетованих вказала на доречність проведення регулярних само- і взаємооглядів, зокрема, серед студентів першого курсу - менше як три четвертих, серед студентів п'ятого - менше ніж дві треті та серед студентів третього курсів - таких понад половини, а серед респондентів інших курсів - менше половини опитаних.

За необхідне звільняти місця для привалів (сну) від сухої трави, гілок і хмизу вважали менше третини респондентів при розмаху варіації від менше однієї п'ятої у студентів четвертого курсу до більш ніж половина опитаних студентів п'ятого курсу.

Незначна частина респондентів не надавала значення застосуванню спеціальних хімічних засобів для захисту від нападу IК. При цьому більш як однієї п'ятої опитаних обрали використання репелентів. Частіше це були студенти першого і п'ятого (менше половини) курсів, рідше - студенти друго- і третьокурсники (менше однієї десятої). Окрім цього, менше третини опитаних зазначила використання інсектицидних засобів з показником вибірки від однієї п'ятої (третій курс) до двох п'ятих (п'ятий курс). Менше однієї п'ятої респондентів вказала на використання акарицидів, більш як десята частина зазначили інсектоакарициди та інсекторепеленти.

Варто зазначити, що лише комплексне застосування всіх заходів, тобто вибір одягу, дотримання правил поведінки під час прогулянки та застосування спеціальних хімічних засобів від IK, може гарантувати максимальний захист. Проте опитані не надавали належного значення цьому питанню, позаяк застосування комплексних заходів характерне найчастіше для близько третини студентів першого та п'ятого курсу, рідше - для третього і другого (близько однієї п'ятої) і дуже рідко - для четвертого (менше однієї п'ятої) курсів.

Аналіз даних статистичного оброблення дозволяє зробити висновки, що спостерігається нерозуміння та розбіжності у відповідях студентів п'ятого курсу, зокрема у питаннях застосування хімічних засобів.

Вакцинація належить до специфічної профрілактики, що спрямована на створення специфрічного імунітету для захисту населення від кліщового вірусного енцесраліту [3]. Як видно з даних таблиці 3, дві п'яті студентів, які зазначили вакцинацію, правильно вказали на доречність застосування її проти кліщового вірусного енцефаліту з показником варіації від дев'яти десятих (у другокурсників) до менше як три четверті (для п'ятикурсників). Проте варто за-

Таблиця 2. Рівні знань студентів щодо заходів захисту від нападу IK за результатами анкетування

\begin{tabular}{|c|c|c|c|c|c|c|}
\hline \multirow{3}{*}{ Заходи захисту } & \multicolumn{5}{|c|}{$\begin{array}{c}\text { Позитивні відповіді студентів з урахуванням курсу } \\
\text { навчання (у \%) }\end{array}$} & \multirow{3}{*}{$\begin{array}{c}\text { Разом } \\
(y \%) \\
N=429\end{array}$} \\
\hline & $\mathrm{I}$ & II & III & IV & $\mathrm{V}$ & \\
\hline & $\mathrm{n}_{1}=70$ & $\mathrm{n}_{2}=81$ & $\mathrm{n}_{3}=113$ & $\mathrm{n}_{4}=96$ & $\mathrm{n}_{5}=69$ & \\
\hline $\begin{array}{l}\text { 1. Вибір верхнього одягу для } \\
\text { прогулянки в парк чи ліс }\end{array}$ & $81,4 \pm 4,6$ & $\begin{array}{c}79,0 \pm \\
2,1\end{array}$ & $\begin{array}{l}69,9 \pm \\
2,5\end{array}$ & $70,8 \pm 0,9$ & $72,6 \pm 9,8$ & $74,3 \pm 4,7$ \\
\hline \multicolumn{7}{|c|}{ 2. Дотримання правил поведінки під час прогулянки: } \\
\hline $\begin{array}{l}2 \text { а) проведення регулярних само- і } \\
\text { взаємооглядів }\end{array}$ & $\begin{array}{c}70,0 \pm \\
5,48\end{array}$ & $\begin{array}{c}46,9 \pm \\
1,65\end{array}$ & $\begin{array}{c}53,0 \pm \\
1,31\end{array}$ & $\begin{array}{c}46,8 \pm \\
1,01\end{array}$ & $59,6 \pm 9,4$ & $\begin{array}{c}54,6 \pm \\
5,19\end{array}$ \\
\hline $\begin{array}{l}2 \text { б) звільнення місця для привалів } \\
\text { (сну) від сухої трави, гілок, хмизу в } \\
\text { радіусі 20-25 м }\end{array}$ & $47,1 \pm 6,0$ & $20,9 \pm 1,1$ & $28,3 \pm 1,6$ & $15,6 \pm 0,7$ & $55,6 \pm 9,0$ & $32,1 \pm 4,7$ \\
\hline \multicolumn{7}{|c|}{ 3. Застосування спеціальних хімічних засобів від ІК: } \\
\hline - інсектицидів & $35,7 \pm 5,7$ & $20,9 \pm 1,1$ & $19,4 \pm 1,3$ & $26,0 \pm 0,9$ & $40,2 \pm 11,0$ & $27,5 \pm 4,7$ \\
\hline - репелентів & $47,1 \pm 6,0$ & $8,6 \pm 0,7$ & $9,7 \pm 0,9$ & $19,1 \pm 0,8$ & $46,7 \pm 11,1$ & $26,4 \pm 4,6$ \\
\hline - акарицидів & $25,7 \pm 5,2$ & $6,1 \pm, 6$ & $9,7 \pm 0,9$ & $\begin{array}{c}8,3 \pm \\
0,6\end{array}$ & $32,4 \pm 10,5$ & $15,4 \pm 3,7$ \\
\hline - інсектоакарицидів & $25,7 \pm 5,2$ & $3,7 \pm 0,5$ & $7,0 \pm 0,8$ & $11,4 \pm 0,7$ & $22,0 \pm 9,5$ & $13,1 \pm 3,5$ \\
\hline - інсекторепелентів & $21,4 \pm 4,9$ & $3,7 \pm 0,5$ & $6,1 \pm 0,7$ & $7,2 \pm 0,8$ & $25,9 \pm 9,9$ & $11,9 \pm 3,4$ \\
\hline Не приділяю цьому значення & - & $1,2 \pm 0,2$ & $2,6 \pm 0,4$ & $7,2 \pm 0,5$ & $2,5 \pm 0,9$ & $3,0 \pm 1,9$ \\
\hline Вакцинація (щеплення) & $38,5 \pm 6,5$ & $38,2 \pm 1,5$ & $53,0 \pm 2,2$ & $29,1 \pm 0,8$ & $46,3 \pm 10,3$ & $41,5 \pm 5,2$ \\
\hline Усі заходи (1+2a+2б+3) & $35,7 \pm 9,9$ & $21,0 \pm 8,9$ & $18,5 \pm 8,1$ & $15,1 \pm 7,3$ & $30,3 \pm 10,3$ & $22,9 \pm 4,0$ \\
\hline
\end{tabular}

ISSN 2312-0967. Фармацевтичний часопис. 2018. № 2 
Фармацевтичний менеджмент, маркетинг та логістика Pharmaceutical management, marketing and logistics

Таблиця 3. Рівні знань студентів, які зазначили вакцинацію щодо специфічної профрілактики природноосередкових захворювань

\begin{tabular}{|c|c|c|c|c|c|c|}
\hline \multirow{3}{*}{ Захворювання, \% } & \multicolumn{5}{|c|}{$\begin{array}{c}\text { Позитивні відповіді студентів } \\
\text { з урахуванням курсу навчання (у \%) }\end{array}$} & \multirow{3}{*}{$\begin{array}{c}\text { Разом } \\
(\text { у \%) } \\
N=178\end{array}$} \\
\hline & 1 & II & III & IV & V & \\
\hline & $\mathrm{n}_{1}=27$ & $\mathrm{n}_{2}=31$ & $\mathrm{n}_{3}=60$ & $\mathrm{n}_{4}=28$ & $\mathrm{n}_{5}=32$ & \\
\hline Кліщовий вірусний енцефраліт & $74,0 \pm 3,3$ & $90,3 \pm 3,3$ & $80,0 \pm 2,3$ & $75,0 \pm 3,3$ & $62,5 \pm 4,9$ & $76,9 \pm 6,2$ \\
\hline Кліщовий висипний тифр & $59,2 \pm 2,9$ & $48,3 \pm 2,4$ & $43,3 \pm 1,7$ & $53,2 \pm 1,7$ & $43,7 \pm 12,0$ & $48,3 \pm 7,3$ \\
\hline Лайм-бореліоз & $37,0 \pm 2,3$ & $25,8 \pm 1,8$ & $46,6 \pm 1,7$ & $25,0 \pm 1,9$ & $46,8 \pm 9,4$ & $38,2 \pm 7,1$ \\
\hline $\begin{array}{l}\text { Гранулоцитарний } \\
\text { людини }\end{array}$ & $22,2 \pm 1,8$ & $9,6 \pm 1,1$ & $26,6 \pm 1,3$ & $35,7 \pm 2,3$ & $12,5 \pm 6,8$ & $21,9 \pm 6,1$ \\
\hline Марсельська гарячка & $18,5 \pm 1,7$ & - & $10,0 \pm 0,8$ & $25,0 \pm 1,9$ & $6,2 \pm 4,9$ & $11,2 \pm 4,6$ \\
\hline $\begin{array}{l}\text { Кримсько-Конго геморагічна } \\
\text { гарячка }\end{array}$ & $18,5 \pm 1,7$ & $12,9 \pm 1,3$ & $6,6 \pm 0,7$ & $3,5 \pm 0,7$ & $12,5 \pm 6,8$ & $10,1 \pm 4,4$ \\
\hline Моноцитарний ерліхоз людини & $11,1 \pm 1,3$ & - & $11,6 \pm 0,9$ & $3,5 \pm 0,7$ & $12,5 \pm 6,8$ & $8,4 \pm 4,1$ \\
\hline Ку-гарячка & $11,1 \pm 1,3$ & - & $6,6 \pm 0,7$ & $7,1 \pm 1,0$ & $15,6 \pm 7,6$ & $7,8 \pm 3,9$ \\
\hline
\end{tabular}

значити, що здебільшого опитані не володіли достатніми знаннями з цього питання, позаяк опитані усіх курсів обрали також інші хвороби. Зокрема, менше половини респондентів вказали, що вакцинація показана проти кліщового висипного тифу, більш ніж третина - проти Лайм-бореліозу. Понад однієї п'ятої анкетованих зазначили, що вакцинація застосовується проти гранулоцитарного анаплазмозу людини, понад десятої частини - КримськоКонго геморагічної гарячки й марсельської гарячки, менше десятої частини Ку-гарячки й моноцитарного ерліхозу людини. Варто вказати, що лише другокурсники у своїх відповідях не зазначили таких захворювань, як марсельська гарячка, моноцитарний ерліхоз людини та Ку-гарячку.

Похибка статистичної оцінки знаходиться в допустимих межах для кліщового вірусного енцефаліту. що стосується інших хвороб, то тут варто зазначити, що студенти не володіють інформацією з приводу захворювань, для попередження яких застосовується вакцинація.
Як зазначалося вище, для неспецифічного захисту від укусів IK $€$ важливим само- і взаємоогляди, які слід проводити що 10-15 хв, а ретельніше - із зніманням та вивертанням одягу, - що дві години (при високій щільності ІК) або через кожні три-чотири години (при низькій щільності ІК). При цьому важливим $€$ знання місць присмоктування (локалізації) IK.

Дані опитування, представлені в таблиці 4, показують, що більшість респондентів вказали, що місцями локалізації ІK є волосисті частини тіла, пахвові ділянки (внутрішня частина плечового згину), шкірні складки. Менше половини опитаних зазначили вушні раковини й пахові ділянки та ін.

Необхідно зазначити недостатній рівень знань студентів 3 цього питання, позаяк невелика кількість студентів (7,5 \%) вказала на всі місця локалізації IK, зокрема це щонайменше одна десята опитаних першого, четвертого і п'ятого курсів і на рівні статистичної помилки - студенти другого і третього курсів. При цьому щодо усіх зазначених місць локалізації та відповіді «не знаю» спостерігається значна статистична розбіжність.

Таблиця 4. Знання студентів щодо місць присмоктування IK

\begin{tabular}{|c|c|c|c|c|c|c|}
\hline \multirow{3}{*}{ Місця локалізації } & \multicolumn{5}{|c|}{$\begin{array}{c}\text { Позитивні відповіді студентів } \\
\text { з урахуванням курсу навчання (у \%) }\end{array}$} & \multirow{3}{*}{$\begin{array}{c}\text { Разом } \\
(\text { у \%) } \\
N=429\end{array}$} \\
\hline & I & II & III & IV & V & \\
\hline & $\mathrm{n}_{1}=70$ & $\mathrm{n}_{2}=81$ & $\mathrm{n}_{3}=113$ & $\mathrm{n}_{4}=96$ & $\mathrm{n}_{5}=69$ & \\
\hline $\begin{array}{l}\text { Пахвові ділянки (внутрішня } \\
\text { частина плечового згину) }\end{array}$ & $72,9 \pm 5,3$ & $44,4 \pm 1,6$ & $48,0 \pm 1,9$ & $60,0 \pm 1,0$ & $76,4 \pm 9,3$ & $58,3 \pm 5,1$ \\
\hline Волосисті частини тіла & $67,1 \pm 5,6$ & $38,2 \pm 1,5$ & $45,1 \pm 2,0$ & $58,3 \pm 1,0$ & $70,0 \pm 9,0$ & $54,8 \pm 5,2$ \\
\hline Шкірні складки & $55,7 \pm 5,9$ & $45,6 \pm 1,6$ & $43,3 \pm 2,0$ & $59,3 \pm 1,0$ & $54,4 \pm 7,3$ & $53,0 \pm 5,2$ \\
\hline Пахові ділянки & $61,4 \pm 5,8$ & $51,8 \pm 1,7$ & $29,2 \pm 1,6$ & $52,0 \pm 1,0$ & $64,5 \pm 8,6$ & $47,7 \pm 5,2$ \\
\hline Вушні раковини & $41,1 \pm 5,9$ & $29,6 \pm 1,3$ & $36,2 \pm 1,8$ & $30,2 \pm 0,9$ & $47,9 \pm 8,1$ & $36,7 \pm 5,0$ \\
\hline Усі зазначені місця & $10,0 \pm 9,4$ & $2,4 \pm 1,0$ & $3,5 \pm 0,7$ & $11,4 \pm 2,2$ & $11,8 \pm 9,5$ & $7,5 \pm 7,4$ \\
\hline Не знаю & $2,8 \pm 3,2$ & - & $0,8 \pm 0,5$ & $1,0 \pm 0,2$ & - & $0,7 \pm 0,6$ \\
\hline
\end{tabular}

ISSN 2312-0967. Pharmaceutical review. 2018. № 2 
Фармацевтичний менеджмент, маркетинг та логістика Pharmaceutical management, marketing and logistics

У подальшому опитуванні з'ясовано, що 219 (51,0 \%) респондентів стикалися 3 укусами IK. Зокрема, 69 (31,5 \%) - через рідних, 66 (30,1\%) - через знайомих, 43 (19,4 \%) - через домашніх тварини та 41 (18,5\%) - особисто. При цьому 132 (60,5 \%) 3 них видаляли IK самостійно і 87 (39,5 \%) зверталися до лікаря. Варто зазначити, що на питання щодо самостійного видалення відповідали студенти, які керувалися власним досвідом або знайомі з досвідом їхніх близьких і родичів.

Як видно 3 даних таблиці 5, одним із способів самостійного видалення IK для більш як чотирьох п'ятих респондентів було використання пінцету. Більше двох п'ятих опитаних використовували петлю 3 нитки. Найчастіше цим методом стикалася більшість студентів другого курсу, найрідше - менше третини п'ятикурсників. Окрім цього, понад двох п'ятих респондентів використовували видалення IK за допомогою спеціальних пристроїв - найчастіше це студенти другого курсу (більш як половина).

Незначна частина студентів (6 \%) видаляла IK просто пальцями рук, що категорично заборонено. Видаляти IK пальцями рук можна, якщо вони обгорнуті марлею, про що зазначило більше третини опитаних за найвищого значення у студентів четвертого (більше половини опитаних) курсу та найнижчого у третьокурсників та п'ятикурсників (менше третини). Усунення IK за допомогою пластикового посуду вказали менше третини студентів п'ятого курсу. Опитані інших курсів з цим не стикалися.

Окрім цього, менше двох третіх студентів використовували комбінований спосіб (заливання ІК рослинною олією + спосіб видалення (окрім відповіді «г») + обробка антисептиком). Найчастіше на це звертали увагу близько двох третіх першокурсників і п'ятикурсників, найрідше - третина третьокурсників. Більше двох п'ятих респондентів зазначили іншу комбінацію (спосіб видалення (окрім відповіді «г») + обробка антисептиком) з розмахом варіації від менше половини третьокурсників до менш ніж третини п'ятикурсників.

Практичного у кожного курсу спостерігається недостатня узгодженість відповідей, що свідчить про користування здебільшого власним досвідом, ніж знаннями при відповіді на питання. Враховуючи те, що мала кількість студентів зазначила спосіб видалення IK пальцями рук, статистичну оцінку виявити було неможливо.

$65(49,2$ \%) із 132 респондентів вказали, що у них та їх рідних виникали неприємні симптоми після самостійного видалення IК. Як засвідчили дані опитування, представлені в таблиці 6, майже дві п'яті з них зазначили біль голови. При цьому всі п'ятикурсники вказали на цей симптом на відміну від третини другокурсників і половини третьокурсників.

Дві третини респондентів зазначили відчуття жару при розмаху варіації від двох четвертих четвертокурсників до чотирьох п'ятих у студентів п'ятого курсу. На загальну слабість вказала більшість опитаних за найменшого значення (дві п'ятих) у студентів першого і третього курсів та найвищого (дві третини) - у другокурсників.

Підвищення температури тіла до 38,5 - $39{ }^{\circ} \mathrm{C}$ зазначило менш як третина анкетованих. Найчастіше цей симптом мали п'ятикурсники (29,2 \%), найрідше - третьокурсники (6,2 \%).

Таблиця 5. Заходи самопомочі при укусі ІК, які застосовували респонденти

\begin{tabular}{|c|c|c|c|c|c|c|}
\hline \multirow{3}{*}{ Заходи самопомочі } & \multicolumn{5}{|c|}{$\begin{array}{c}\text { Позитивні відповіді студентів } \\
\text { з урахуванням курсу навчання (у \%) }\end{array}$} & \multirow{3}{*}{$\begin{array}{c}\text { Разом } \\
(\mathrm{y} \%) \\
\mathrm{N}=132\end{array}$} \\
\hline & I & II & III & IV & V & \\
\hline & $\mathrm{n}_{1}=32$ & $\mathrm{n}_{2}=24$ & $\mathrm{n}_{3}=32$ & $\mathrm{n}_{4}=18$ & $\mathrm{n}_{5}=26$ & \\
\hline \multicolumn{7}{|c|}{ Способи самостійного видалення IK: } \\
\hline а) пінцетом & $90,6 \pm 8,2$ & $70,8 \pm 11,4$ & $78,1 \pm 9,9$ & $83,3 \pm 10,5$ & $84,6 \pm 10,8$ & $82,5 \pm 4,9$ \\
\hline б) петлею з нитки & $46,8 \pm 12,5$ & $54,1 \pm 14,3$ & $37,5 \pm 11,7$ & $44,4 \pm 15,2$ & $30,7 \pm 7,4$ & $42,2 \pm 3,3$ \\
\hline в) спеціальними пристроями & $37,5 \pm 11,7$ & $58,3 \pm 14,3$ & $40,6 \pm 12,4$ & $38,8 \pm 16,1$ & $46,1 \pm 14,9$ & $43,9 \pm 5,2$ \\
\hline г) просто пальцями рук & 6,2 & 8,3 & 6,2 & 5,5 & 3,8 & 6,0 \\
\hline $\begin{array}{l}\text { д) пальцями рук, обгорнутими } \\
\text { марлею }\end{array}$ & $34,3 \pm 11,8$ & $37,5 \pm 12,3$ & $28,1 \pm 11,4$ & $55,5 \pm 14,3$ & $28,6 \pm 16,5$ & $37,1 \pm 3,5$ \\
\hline ж) пластиковим посудом & - & - & - & - & $30,7 \pm 7,4$ & 6,0 \\
\hline $\begin{array}{l}\text { Місце укусу } \\
\text { антисептиком }\end{array}$ & $90,6 \pm 6,1$ & $91,6 \pm 4,2$ & $71,8 \pm 10,2$ & $88,8 \pm 9,8$ & $92,3 \pm 5,8$ & $91,6 \pm 3,3$ \\
\hline Заливали ІК рослинною олією & $56,2 \pm 11,1$ & $66,6 \pm 13,9$ & $31,2 \pm 10,5$ & $50,0 \pm 14,9$ & $73,0 \pm 11,4$ & $53,7 \pm 5,2$ \\
\hline $\begin{array}{l}\text { Спосіб видалення (окрім г) + } \\
\text { обробка антисептиком }\end{array}$ & $40,6 \pm 12,4$ & $37,5 \pm 12,3$ & $46,8 \pm 12,9$ & $44,4 \pm 15,2$ & $30,7 \pm 7,4$ & $45,4 \pm 4,9$ \\
\hline $\begin{array}{l}\text { Рослинна олія + спосіб видалення } \\
\text { (окрім г) + обробка антисептиком }\end{array}$ & $67,2 \pm 12,9$ & $62,5 \pm 14,1$ & $34,3 \pm 10,8$ & $61,1 \pm 15,2$ & $69,2 \pm 11,9$ & $64,3 \pm 4,1$ \\
\hline
\end{tabular}

ISSN 2312-0967. Фармацевтичний часопис. 2018. № 2 
Фармацевтичний менеджмент, маркетинг та логістика Pharmaceutical management, marketing and logistics

Таблиця 6. Неприємні симптоми, які виникли опісля самостійного видалення ІК

\begin{tabular}{|c|c|c|c|c|c|c|}
\hline \multirow{3}{*}{ Симптоми } & \multicolumn{5}{|c|}{$\begin{array}{c}\text { Позитивні відповіді студентів } \\
\text { з урахуванням курсу навчання (у \%) }\end{array}$} & \multirow{3}{*}{$\begin{array}{c}\text { Разом } \\
(y \%) \\
N=65\end{array}$} \\
\hline & I & II & III & IV & V & \\
\hline & $\mathrm{n}_{1}=14$ & $\mathrm{n}_{2}=14$ & $\mathrm{n}_{3}=16$ & $\mathrm{n}_{4}=14$ & $\mathrm{n}_{5}=7$ & \\
\hline Біль голови & 78,5 & 35,7 & 50,0 & 78,5 & 100 & 70,0 \\
\hline Відчуття жару & 71,4 & 57,1 & 43,7 & 71,4 & 85,7 & 60,3 \\
\hline Загальна слабість & 42,8 & 64,2 & 43,7 & 57,1 & 57,1 & 52,3 \\
\hline Підвищення t до 38,5-39 C & 21,4 & 42,8 & 6,2 & 35,7 & 57,1 & 29,2 \\
\hline Нудота і блювання & 42,8 & - & 6,2 & 14,2 & 42,4 & 18,4 \\
\hline Запаморочення & 7,1 & - & 6,2 & 7,1 & - & 4,6 \\
\hline
\end{tabular}

На нудоту і блювання вказали менш як одна п'ята респондентів. Другокурсники не вказали на цей симптом. При цьому нудоту і блювання найчастіше (понад двох п'ятих) спостерігали студенти першого і п'ятого курсів, значно рідше (14,2 \%) - студенти четвертого і ще рідше (6,2 \%) - третього курсів. Лише поодинокі студенти мали запаморочення (4,6 \%) і це студенти третього (6,2 \%) та першого і четвертого (по 7,1 \%) курсів.

Зважаючи на те, що курс епідеміології відсутній у навчальному плані підготовки магістрів фрармації, наступним етапом нашого дослідження був аналіз навчальних планів, таких дисциплін, як: «Біологія 3 основами паразитології», «Мікробіологія з основами імунології» та «Клінічна фрармація», де б студенти могли вивчати IК. Встановлено, що студенти-провізори 3 дисципліни «Біологія з основами паразитології» вивчають загальні аспекти, зокрема, будову кліщів та їхні види у процесі заняття: «Тип Членистоногі (Arthropoda) Клас Павукоподібні (Arachnoidea). Кліщі (Acarina) - збудники хвороб та переносники збудників захворювань людини». При цьому дисципліна «Мікробіологія 3 основами імунології» не містить жодного заняття, де б мова йшла про кліщі. Аналізуючи навчальний план дисципліни «Клінічна фрармація», виявлено, що у процесі теми заняття «Стани, які легко підлягають медикаментозній корекції й віднесені до самолікування. ОТС-засоби їх вибір для забезпечення самолікування (вугрової хвороби та інші ураження шкіри, опіках, корості, тощо). Фармацевтична опіка при застосуванні ОТС-засобів», студенти четвертого курсу вивчають таке захворювання, як короста, збудниками якого $€$ не IK, а кліщі іншого виду. Таким чином, студенти-провізори упродовж всього освітнього процесу не вивчають питання запобігання зараженню збудниками небезпечних трансмісивних інфекційних захворювань, переносниками яких є IK.

Висновки 1. Шляхом анкетного опитування 429 студентів-провізорів першого-п'ятого курсів денної форми навчання встановлений недостатній рівень їх знань щодо надання фрармацевтичної допомоги з питань запобігання зараженню небезпечними трансмісивними інорекційними захворюваннями, переносниками яких $€ \mathrm{IK}$.

2. Зважаючи на автономність закладів вищої освіти та відсутність курсу епідеміології у підготовці магістрів фрармації, актуально внести зміни в навчальні плани університетів фрармацевтичного спрямування, зосередивши увагу на захворюваннях, збудниками яких $€ \mathrm{IK}$, а також на засобах індивідуальної неспецифічної профрілактики цих інфрекцій, зокрема аптечного асортименту.

\section{ОСОБЕННОСТИ ПОНИМАНИЯ СТУДЕНТАМИ-ПРОВИЗОРАМИ ПРОБЛЕМЫ ПРЕДУПРЕЖДЕНИЯ КЛЕЩЕВЫХ ТРАНСМИССИВНЫХ ПРИРОДНО-ОЧАГОВЫХ ИНФЕКЦИЙ}

\section{О. А. Палюх ${ }^{1}$, Б. П. Громовик1, Н. А. Виноград ${ }^{1}$, Г. И. Билущак ${ }^{2}$}

Львовский национальный медицинский университет имени Данила Галицкого ${ }^{1}$ Национальный университет «Львовская политехника»²

oksana.paliuh@gmail.com,hromovyk@gmail.com, vynogradno@ukr.net, gbilushak@gmail.com

Цель работы. Исследование уровня знаний студентов-провизоров дневной фрормы обучения о возможности предоставления фрармацевтической помощи по вопросам предотвращения заражения возбудителями опасных трансмиссивных иноекционных заболеваний, переносчиками которых являются иксодовые клещи (ИК).

Материалы и методы. Для сбора первичных данных использовали очно-заочный опрос с использованием анкеты

ISSN 2312-0967. Pharmaceutical review. 2018. № 2 
Фармацевтичний менеджмент, маркетинг та логістика

Pharmaceutical management, marketing and logistics

открытого типа. Получено 443 анкеты, из которых отобрано и обработано 429 качественно заполненных анкет. Статистический анализ граничной погрешности доли проводился с использованием табличного процессора Microsoft Office.

Результаты и обсуждение. Установлено, что, по мнению более трех четвертых студентов, ИК является, прежде всего, переносчиками возбудителей клещевого энцефалита. Однако несколько меньше одной третьей опрошенных отметили в своих ответах, что ИК являются возбудителями чесотки, хотя это заболевание вызывает клещ Sarcoptes scabiei. Около трех четвертых студентов считали, что для предотвращения укусов ИК целесообразно одеваться в светлую однотонную с длинными рукавами плотно прилегающую к телу одежду. Более половины анкетируемых отметили уместность проведения регулярных само- и взаимоосмотров, а более одной пятой - использование репеллентов как химических средств защиты. Однако применение комплексных мер защиты было характерно лишь для более пятой части опрошенных. Две пятых студентов правильно отметили уместность применения вакцины против клещевого вирусного энцефралита. Однако опрошенные всех курсов неправильно выбрали вакцинацию для других болезней. Все без исключения студенты были не ознакомлены с возможными местами локализации ИК. Более двадцатой части студентов, которые сталкивались с укусами Ик, удаляли их просто пальцами рук, что категорически запрещено. Менее двух третьих студентов использовали комбинированный способ удаления ИК. Результаты изучения учебного плана показали, что студенты-провизоры в течение всего образовательного процесса не изучают вопрос предотвращения заражения возбудителями опасных трансмиссивных инорекционных заболеваний, переносчиками которых являются ИК.

Выводы. Путем анкетного опроса 429 студентов-провизоров первого-пятого курсов дневной формы обучения установлен недостаточный уровень их знаний о предоставлении фрармацевтической помощи по вопросам предотвращения заражения опасными трансмиссивными инфекционными заболеваниями, переносчиками которых являются ИК. Принимая во внимание автономность высших учебных заведений и отсутствие курса эпидемиологии в подготовке магистров фрармации, актуально внести изменения в учебные планы университетов фармацевтического направления, сосредоточив внимание на заболеваниях, возбудителями которых являются ИК, а также на средствах индивидуальной неспецифической профилактики этих инфекций, в частности аптечного ассортимента.

Ключевые слова: иксодовые клещи; природно-очаговые инфекции; студенты-провизоры; уровень знаний.

\section{FEATURES OF STUDENTS' INTELLIGENCE OF PROBLEMS OF PREVENTION OF WIRELESS TRANSMISSIBLE NATURAL AND ENVIRONMENTAL INFECTIONS}

\section{O. A. Paliukh ${ }^{1}$, B. P. Hromovyk' ${ }^{1}$, H. O. Vynograd ${ }^{1}$, G. I. Bilushak ${ }^{2}$}

Danylo Halytsky Lviv National Medical University ${ }^{1}$, National University «Lviv Polytechnic»»

oksana.paliuh@gmail.com,hromovyk@gmail.com, vynogradno@ukr.net, gbilushak@gmail.com

The aim of the work. A study of the level of knowledge of full-time student-pharmacists in relation to the possibility of providing pharmaceutical assistance on the prevention of pathogenic infections of dangerous transmissible infectious diseases, which carriers are ixodic ticks (IM).

Materials and Methods. For the collection of primary data, an on-the-spot questionnaire with open-ended questions was used. 443 questionnaires were received, of which 429 qualitatively completed questionnaires were selected and processed. The statistical analysis of the marginal error of the particle was conducted using the Microsoft Office table processor.

Results and Discussion. It has been established that, according to more than three-fourths of the students, the immune system is primarily a carrier of pathogens of tick-borne encephalitis. However, slightly less than one third of the respondents indicated in their responses that inflammatory agents are scabies, although this disease is caused by the Sarcoptes scabiei mite. About three-fourths of students believed that in order to prevent bite of IM it is advisable to dress in light monotonous, long-sleeved, tight-fitting clothes. More than half of the respondents highlighted the importance of regular self and mutual examinations, and more than one-fifth - the use of repellent as a chemical protection means. However, the use of complex protection measures was characteristic only for more than a fifth of respondents. Two-fifths of the students correctly pointed out the relevance of the vaccine against tick-borne encephalitis. However, all of the interviewed subjects misdiagnosed other vaccine-related illnesses. All students without exception were not familiar with the possible places of localization of the IM. More than twenty students, who have encountered bite infections, have removed them with their fingers, which is strictly prohibited. Less than two thirds of students used a combined method of removing the IM. The results of studying the curriculum have shown that students-pharmacists throughout the educational process do not study the issue of preventing infectious agents from dangerous transmissible infectious diseases, the carriers of which are IM.

ISSN 2312-0967. Фармацевтичний часопис. 2018. № 2 
Conclusions. By means of interviewing 429 full-time studying students-pharmacists of the I-V years, an inadequate level of their knowledge regarding the provision of pharmaceutical assistance on the prevention of the transmission of dangerous transmissible infectious diseases, the carriers of which is IM, was shown. Taking into account the autonomy of higher education institutions and the lack of an epidemiology course in the preparation of masters of pharmacy, it is important to make changes in the curricula of pharmaceutical universities, focusing on diseases caused by IM as well as on individual non-specific means of prevention from these infections, in particular in pharmaceutical assortment.

Key words: ixodes mites; natural-focal infections; students-pharmacists; level of knowledge.

\section{Список літератури}

1. Про затвердження Методичних рекомендацій «Неспецифічна профрілактика трансмісивних природновогнищевих інфекцій, що передаються іксодовими кліщами» : наказ МОЗ України № 369 від 13.05.2013 р. [Електронний ресурс]. - Режим доступу до інфрормації: http: //mozdocs.kiev.ua/view.php?id=14473

2. Про посилення заходів з діагностики та профілактики іксодових кліщових бореліозів в Україні : наказ МОЗ України № 218 від 16.05.2005 р. [Електронний ресурс]. - Режим доступу до інфрормації: http: //mozdocs.kiev.ua/view.php?id=4052

3. Про вдосконалення заходів профрілактики кліщового вірусного енцефаліту в Україні : наказ МОЗ України

\section{References}

1. Order of the Ministry of Health of Ukraine No. 369 dated May 13, 2013 "On Approval of Methodical Recommendations" Non-specific prevention of transmissible natural-focal infections, transmitted by ioxin mites. Electronic resource: http: //mozdocs.kiev.ua/view.php?id=14473. Ukrainian.

2. The Order of the Ministry of Health of Ukraine No. 218 dated May 16, 2005 "On the Strengthening of Measures for the Diagnosis and Prevention of Ixod Pimple Borelios in Ukraine". Electronic Resource http: //mozdocs.kiev.ua/ view.php?id=4052. Ukrainian.
№ 431 від 30.08.2005 р. [Електронний ресурс]. Режим доступу до інфрормації: http://consultant.parus. ua/?doc $=02$ WU74DC32

4. Инорормационное письмо «О неспецифической профрилактике клещевого вирусного энцесралита, иксодовых клещевых боррелиозов, крымской геморрагической лихорадки и других инфекций, возбудителей которых передают иксодовые клещи (по состоянию на 01.01.2014)» [Электронный ресурс] / Н. В. Шестопалов, Н. И. Шашина, О. М. Германт и др. - 23 с. Режим доступа до информации: http://www.niid.ru/s/210/ files/press/release/105552_478.Pdf

3. Order of the Ministry of Health of Ukraine No. 431 dated August 30, 2005 "On the improvement of preventive measures for tick-borne encephalitis in Ukraine". Electronic resource http://consultant.parus.ua/?doc=02WU74DC32. Ukrainian.

4. Shestopalov NV, Shashina NI, Germant OM. Information letter "On nonspecific prophylaxis of tick-borne virus encephalitis, ixodid tick-borne borreliosis, Crimean hemorrhagic fever and other infections, the causative agents of which are transmitted by ixodid mites (as of 01.01.2014)". Electronic resource http://www.niid.ru/s/210/files/press/release/105552_478.Pdf. Ukrainian. 